\title{
Characteristics of Agricultural Commodity Financing Based on Warehouse Receipt System in Indonesia
}

\author{
Karmex Siadari $^{*} \quad$ M.Syamsul Maarif ${ }^{1} \quad$ Bustanul Arifin $^{2} \quad$ Zulkifli Rangkuti $^{3}$ \\ 1.School of Business, IPB University, Jl. Pajajaran, Bogor 16151, Indonesia \\ 2.Department of Agriculture Economics and Social Science, Lampung University and Institute for Development \\ of Economics and Finance (INDEV) \\ 3.College of Management IMMI Jakarta, Jl. Tanjung Barat No.11 Jakarta Selatan, 12510, Indonesia
}

\begin{abstract}
Agricultural commodities financing based on warehouse receipt system is empirically beneficial to support rural agricultural businesses. However, the success of the system is influenced by a number of factors. The objective of this study is to characterize the factors of the warehouse receipt financing system where it is implemented in agricultural commodity in Indonesia. The research was conducted by means of a survey that collected data from respondents with knowledge of or experience on financing of commodities such as coffee, pepper, rice and maize. Partial Least Squares-Structural Equation Modeling (PLS-SEM) was used as the analysis model. The research results indicate that the warehouse receipt financing system suitable for development in Indonesia is characterized by social and commercial value. The product value must be supported by product attributes to ensure the availability, acceptability, accessibility, affordability and supply of information to provide awareness and trust in accordance with the values built in the financing product. This study can also prove that adding adaptability to product variables increases market acceptance.
\end{abstract}

Keywords: Agricultural Commodities, Structured Financing, Warehouse Receipt System

DOI: $10.7176 / \mathrm{JESD} / 12-6-06$

Publication date:March $31^{\text {st }} 2021$

\section{Introduction}

Warehouse receipt financing system is empirically a suitable concept implemented to increase access to finance in agricultural business. The warehouse receipt financing is unique compared to conventional financing systems. Some factors such as market conditions, commodity price volatility and commodity risk are included as considering factors when building commodity financing. The basic structure of commodity financing of warehouse receipt financing system is simply illustrated in Figure 1.

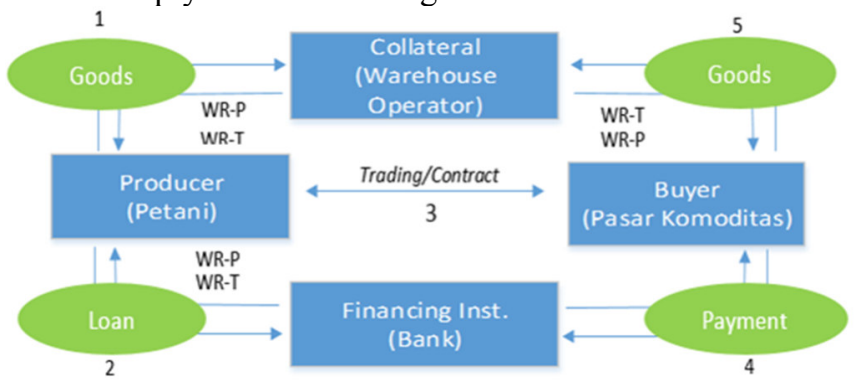

WR-P (financing); WR-T (repayment)

Figure 1. Basic Scheme of Structured Commodity Financing

(Source: Varangis and Larson, 2002; MacNamara, 2001; Rutten, 2015)

The financing process begins by the delivery of a specified quantity and quality of tradable goods to the storage warehouse, where it is received by collateral manager. Warehouse receipt is issued in accordance to the goods delivered. Based on commodity documents or warehouse receipts and supported by available market price for reference, the financial institution calculates the price of the commodity prior to lending for a specified portion of the commodity. The goods listed on the warehouse receipt become legal collateral for financing purpose (WRP) after a legal guarantee binding. The next stage is to release the goods from the warehouse or return the warehouse receipt transferred (WR-T) to the owner or a designated party according to the agreement between both parties or after repayment of the loan. The financing schemes reflecting repayment capability said a self-liquidating structured financing (MacNamara, 2001; Miranda 2018). The cycle of self-liquidating structured commodity financing is generally relatively short and lasts less than one year. In some countries it varies between $30,60,90$, 180 days according to the asset conversion circle (Sutak 2008; Rutten 2015; Miranda 2018).

According to some studies on warehouse receipt system and its financing (Sutak, 2008; Varangis and SaintGeours, 2013; Jovicic et al., 2014; Rutten, 2015; Wang et al., 2018; Miranda, 2018) and reports such as World Bank (2013) and (IFC 2015), warehouse receipt financing is successfully implemented in some countries and 
benefiting for agricultural farmers. Warehouse receipt financing provides benefits such as market access, access to finance, reducing market risk, increasing profits, gaining more knowledge, flows of information and added social and environmental impact to the farmer. However, in the case of Indonesia, warehouse receipt system has been implemented over a decade. However, the system are still adjusting and looking for the right model. Several studies has been conducted with several findings. Ashari (2012) and Suryani et al (2014) stated the needs of bureaucracy and governance support to enable warehouse receipt system development in Indonesia. Listiani (2013), Bustamin (2014) and Gunawan et al (2019) stated that information provision and knowledge play a more important role for development of the warehouse receipt system (SRG) in Indonesia. In addition, some studies on other countries as comparison, Coulter and Onumah (2010) in Malawi identified product value, infrastructure, institutions, regulations, knowledge, expertise, commitment and stakeholder trust are the essential factors when developing warehouse receipt financing. Gashayie and Singh (2015) in India cited political factors, legality, operational systems, infrastructure and technology supporting value chain systems as essential for the development of warehouse receipt financing. Katunze et al (2017) in Africa stated that the market condition of supply and demand of commodities that influencing commodity prices is an essential factor to develop warehouse receipt financing. The above information shows different element of factors which become determinants to build warehouse receipt financing system and no consensus is defined as standard, each country has its characteristics. Based on the information above, on this articles are aimed to characterization of suitable warehouse receipt financing system in accordance with Indonesian environmental situation.

\section{Theoretical Review}

Few theoretical references to explain the above issues of characterization of agricultural commodity financing systems to be developed in Indonesia. Kohler's (2009) in product theory mentioned product value is the core reason for individuals or companies to purchase goods or services and its refer to core value, actual value and added value. Becchetti and Conzo (2009) stated that the product should be accepted on the basis of its product attributes such as availability, accessibility, acceptability and affordability, Stiglitz and Weiss (1981) and Capacio et al (2018) stated that the customer must supplied by information and knowledge to build awareness and trust in the products, It must be supported by the provision of information and knowledge of and experience with the products. However, Teece (1997) and Wang and Ahmed (2007) added with the need of flexibility to respond to environment conditions to make the product adaptable with dynamic changes.

Agricultural commodity financing is part of finance products and included in finance theory. Classical theory financing is activities to raise funds and channel loans to the public (Mettenheim, 2013). Financing is made by basic of acceptance of a credit agreement by both borrower and financier and each party has the liberty to choose and accept the financial value as stated in the agreement. According to financial theory, Modigliani and Miller (1958) state that in capital structure theory, the use of external financing is determined by the benefits of using debt, since the occurrence of debt costs can be used as a tax deduction and is referred to by Kraus, A. and Litzenberger, RH (1973) as the trade-off theory of comparison between costs and benefits. Meanwhile, another view is the pecking order theory, found by Donaldson and developed by Myers and Majluf (1984), which emphasizes that companies first optimize their internal sources of funding (internal equity) because internal sources of funding are considered cheaper than external sources. The above theories provide an overview of the differences in determining the source of financing. Fama and French (2002) state that the decision to choose a source of funding is different for each company. Corporate companies have strong credit characteristics, economies of scale, the availability of collateral and business capacity and it is relatively easy to obtain external sources of financing. However, this differs from micro, small and medium scale companies which have weak credit characteristics, small-scale business size and limited collateral availability, making the ability to obtain external funding sources relatively difficult. The characteristics of the problems faced by micro, small and medium-sized entreprisses are vary. Small and medium-sized enterprises have limitations in some areas i.e. terms of payment capacity, availability of collateral (collateral), and a lack of expertise in managing finances (Hananu B. et al., 2015).

Based on the background of theoretical literature and empirical study, this research is an analysis of the characteristics of agriculture commodity finance in a warehouse receipt system suitable for development in Indonesia with the additional hypothesis that product flexibility increases product acceptability. The conceptual model to measure the acceptability of financing products for agricultural commodities in the warehouse receipt system are using the following factors. First, the value factor consists of the core value, real or actual and added value. Second, product attribute factors include delivery and marketing side. Third, information flows, and fourth, the ability to adjust the values and attributes of product to environmental conditions. The building of characteristic factors, as shown in Figure 2. 


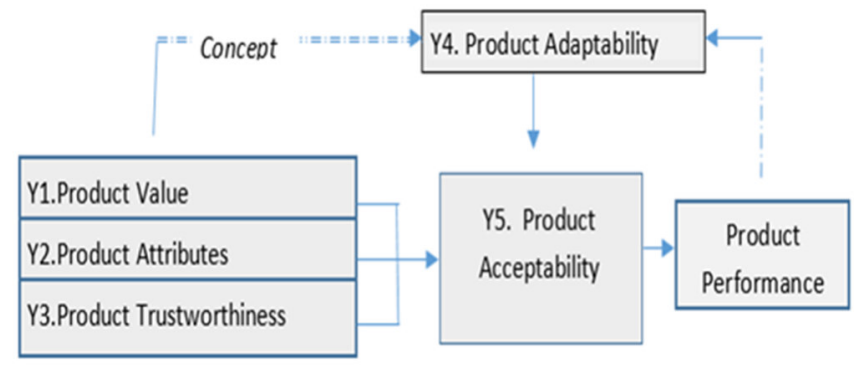

Figure 2. Assessment of Product Acceptability Factors

Product acceptability is determined by product values, product attributes, product trustworthiness and product adaptability (concept). Product acceptability variable $\left(\mathrm{Y}_{5}\right)$ in the conceptual structure is indicated by following measured variables:

$\mathrm{Y}_{1}=\mathrm{X}_{1}+\mathrm{X}_{2}+\mathrm{X}_{3}+\mathrm{X}_{4}+\mathrm{X}_{5}$

$\mathrm{Y}_{2}=\mathrm{X}_{6}+\mathrm{X}_{7}+\mathrm{X}_{8}+\mathrm{X}_{9}$

$\mathrm{Y}_{3}=\mathrm{X}_{10}+\mathrm{X}_{11}+\mathrm{X}_{12}$

$\mathrm{Y} 4=\mathrm{X}_{13}+\mathrm{X}_{14}$

- Product value $\left(\mathrm{Y}_{1}\right)$ is built up by independent variables, including core value $\left(\mathrm{X}_{1}\right)$, actual value $\left(\mathrm{X}_{2}\right)$, added value $\left(\mathrm{X}_{3}\right)$ with added aspects of social value $\left(\mathrm{X}_{4}\right)$ and environmental value $\left(\mathrm{X}_{5}\right)$ in the concept of sustainability.

- Product Attribute $\left(\mathrm{Y}_{2}\right)$ is built by independent variables, including availability $\left(\mathrm{X}_{6}\right)$, acceptability $\left(\mathrm{X}_{7}\right)$, accessibility $\left(\mathrm{X}_{8}\right)$ and affordability $\left(\mathrm{X}_{9}\right)$.

- Product trustworthiness $\left(\mathrm{Y}_{3}\right)$ is based on product information $\left(\mathrm{X}_{10}\right)$, product knowledge $\left(\mathrm{X}_{11}\right)$ and comfort $\left(\mathrm{X}_{12}\right)$.

- Product Adaptation $\left(\mathrm{Y}_{4}\right)$ is supported by the ability to respond to feedback or environmental changes with optimal value $\left(\mathrm{X}_{13}\right)$ and product attributes $\left(\mathrm{X}_{14}\right)$.

The conceptual construction model of the relationship between the variables and dimensions above is described in exogenous variables or manifest variables and endogenous variables or latent variables as described in Figure 3.

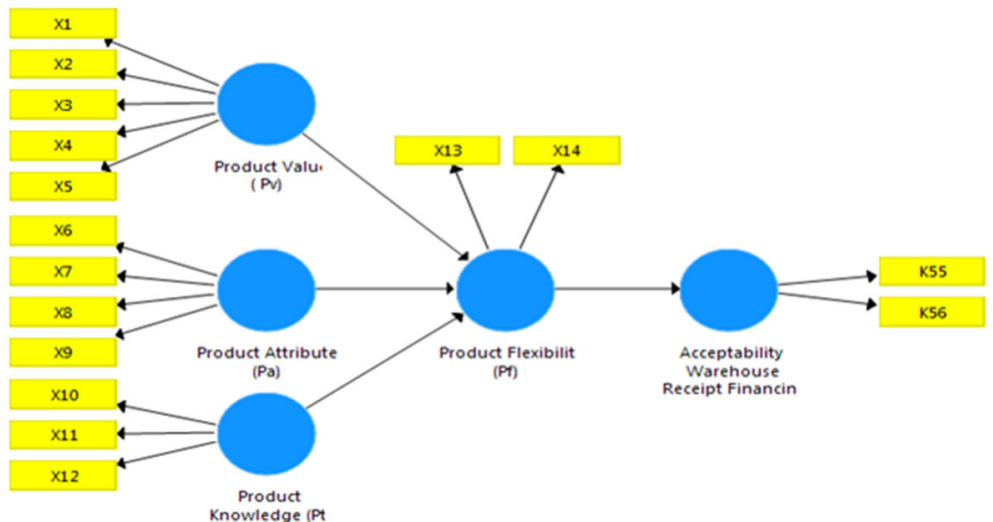

Figure 3. Conceptual construction model for adaptable WRF Financing

Hypothesis Stage 1: Product flexibility affects the continuity and sustainability of the acceptability of the product $(\mathrm{Y} 4 \rightarrow \mathrm{Y} 5)$

\section{Method}

This study uses a quantitative descriptive method, which provides an overview of an event or symptom at a particular location. The research was conducted on production sites of commodities such as coffee, pepper, rice and maize, which are located in several regions of the islands of Java and Sumatra. Respondents were deliberately selected who have knowledge of or experience in the financing of agricultural commodities based on warehouse receipt systems, such as farmer groups or farmers' cooperatives, collectors or traders of agricultural commodities, financial service institutions (banks) and financial support institutions such as warehouse managers, insurance, and commodity market appraisers. The survey and data processing was conducted from August 2019 to September 2020 . 


\subsection{Research Location}

The research took place along the goods chain from upstream (commodity producers) to downstream (commodity intermediaries) and supporting institutions associated with the warehouse receipt financing system, from micro to corporate scale. First, commodity producers, who are mostly a farming community, prefer a regulated warehouse receipt system. Based on BAPPEBTI data (2018) there are about 89 government warehouses available to support farmers with a warehouse receipt system, however only few have implemented a warehouse receipt system, such as Koperasi Mukti Niaga (Cianjur, West Java), PT. Mitra Desa Cisuka (Tasikmalaya, West Java), KSU Annisa (Subang, West Java), KSU Sarana Hidup Sejahtera (Grobogan, Central Java), Koperasi Kelompok Usaha Serbajadi (Natar, Lampung) and KUD Sepakat (Candipuro, Lampung) which have implemented a warehouse receipt system for the commodities rice, grain and maize. Others like PT. Ketiara (Takengon, Aceh) and KSU Annisa (Subang, West Java) are in the early stages of including coffee into the system. Second, traders, business integrators such as collectors and traders who have applied for or have experience of using commodity financing services with a warehouse receipt system include for example PT Sinar Uni Grain (Surabaya, East Java) and PT. Inensunan Mills Indonesia (Jakarta) for rice and maize commodities; PT.Indra brother (Tanjung Karang, Lampung) and PT Sarimakmur Tunggal Mandiri (Medan, North Sumatra) for coffee and PT Multi Organik Internasional and PT Putrabali Adyamulia (Tanjung Karang, Lampung) for the commodity of coffee and pepper. Third, financing institutions, financing institutions in this study are staff of banking institutions that have experience in facilitating commodity financing. Some listed private banks or national banks are experienced in financing commodity warehouse receipt systems such as Rabobank, Deutsche Bank, Standard Charter Bank, CIMB Niaga, Bank Danamon, Bank BPD East Java and Bank West Java BPD. Four, support institutions, support institutions include warehouse management, collateral management, registry office and insurance. Support institutions include PT. Bhanda Ghara Reksa (BGR), PT.Sucofindo, PT. Kliring Berjangka Indonesia (KBI) and PT. Mars Insurance.

\subsection{Types and Sources of Data}

The data used in this study consisted of primary data that were obtained through surveys using questionnaires to collect data from respondents who have an understanding of or experience with the warehouse receipt financing system for at least 1 year and secondary data that were obtained from various representative sources providing information related to commodity financing through warehouse receipt systems.

\subsection{Method of Analysis}

The method of analysis uses analysis based on the Structural Equation Modeling - Partial Least Square (SEM-PLS) model (Rahim et al., 2001; Wong 2006; Chin et al., 2003). SEM-PLS is considered more powerful and capable of overcoming the limitations of SEM model assumptions in this study. First, it is a component-based approach with a more predictive orientation. The construct is defined as the number of element indicators for each PLS algorithm to obtain the best weight estimate for each indicator according to each latent construct with outer model and inner model to measurable exogenous and endogenous variable. Second, to test the effect of indicators for theoretical confirmation that can show possible relationships and suggest propositions for further testing. Third, the PLS measurement model is optimized as reflective and formative indicators in conjunction with the structural model. Fourth, there is a limited amount of data and therefore does not meet the criteria for multivariate normal distribution. This condition violates the assumptions of covariance-based SEM methods such as LISREL which requires a large sample size. In LISREL SEM the minimum sample size is 200, but in PLS small data is allowed. The PLS assumption uses sample data with a minimum size of 30 (Wong, 2006 P: 183). Fifth, PLS allows more flexibility in measurement scale (e.g. ratio, multiple choice) and quantitative data was analyzed in the form of figures and tables based on SEM-PLS analysis. The assessment includes weightings or factor values to obtain an overview of the influence of factors on the dependent variable.

The data from the research results is then interpreted by the SEM-PLS factor analysis using the load factor to measure the validation of the accessibility variable indicators and the composite reliability values to measure the accuracy of the measuring instruments or measure the extent to which the measuring instruments used can measure what has been measured (Chin 1988). The formulation of the indicator validity test is determined by the formula: $\mathrm{r}_{\mathrm{xy}}=\left(\mathrm{n} \Sigma_{\mathrm{xy}}-\Sigma_{\mathrm{x}} \Sigma_{\mathrm{y}}\right) /\left(\sqrt{ }\left(\left(\mathrm{n} \Sigma_{\mathrm{x}}^{2}-\left(\Sigma_{\mathrm{x}}\right)^{2}\left(\mathrm{n} \Sigma_{\mathrm{y}}^{2}-\left(\mathrm{n} \Sigma_{\mathrm{y}}\right)^{2}\right)\right)\right.\right.$

- Where, correlation coefficient $\left(\mathrm{r}_{\mathrm{xy}}\right)$ between variables $\mathrm{x}$ and $\mathrm{y}$ - $\quad r_{x y} \geq r$ table $(0.5)$ (accepted).

Analysis of the reliability or level of confidence in the measurement of variable construct reliability is measured by Cronbach's composite reliability (r) or Cronbach's ( $\mathrm{r}$ ) as follows.

$\mathrm{r}=(\mathrm{n} /(\mathrm{n}-1))\left(1-\left(\Sigma \sigma_{\mathrm{t}}^{2} / \sigma_{\mathrm{t}}^{2}\right)\right)$

- Where, $\mathrm{r}=$ reliability sought; $\mathrm{n}=$ number of question items tested; $\Sigma \sigma^{2}=$ amount of variance in the score of each item; $\sigma_{\mathrm{t}}^{2}=$ Total variance; Alpha Cronbach $(\mathrm{r})>0.7$ (sufficient 
reliability); Cronbach alpha $<0.5$ (low reliability); 0.5 alpha $<0.7$ (moderate reliability).

Hypothesis testing, SEM-PLS does not assume that the data is normally distributed and non-probabilistic, however the normality is available by PLS bootstrapping to test significance (Wong, 2006 P: 182). Determination of the confirmation of the relationship between factors or latent variables is determined by indicators; among others: First, R square measures to what extent the model is able to explain the variation of the dependent variable; according to Chin et al (2003) R square $>0.67$ (strong), R square $>0.33$ (moderate) and R square $>0.19$ (weak). Second, the decision about the relevance of the variable relationship was determined by the predictive relevance $\mathrm{Q}^{2}$ value as follows: $\mathrm{Q}^{2}=1-\left(1-\mathrm{R} 1^{2}\right)\left(1-\mathrm{R} 2^{2}\right)$. The importance of calculating the value of $\mathrm{Q}^{2}$ or predictive relevance means that the observed value generated by the structural model has predictive relevance suitable for use in research. According to Ghozali (2011) a construct has good predictive relevance if it has a value of $\mathrm{Q}^{2}>0$. Third, the significance of the relationship, PLS has a bootstrapping process to iterate the sample, so the normality can be obtained through the $\mathrm{t}$-value. The $\mathrm{t}$-value is compared to the statistical $\mathrm{t}$-value with a significant $95 \%(\alpha=0.05)$ for the hypothesis test; $\mathrm{H}_{0}=0$ or $\mathrm{t}$-count $\leq \mathrm{t}$-table 0.5 (hypothesis is rejected) or $\mathrm{H}_{1} \neq 0$ or $\mathrm{t}$-count $\geq \mathrm{t}$-table (hypothesis is accepted) for inner model. The test statistic used is the t-test, with the formula, to test the inner model.

\section{The Results}

\subsection{Respondent description}

The primary data of this study was collected from a group of respondents to confirm consumer acceptability in the commodity financing warehouse receipt system in Indonesia as illustrated in Figures 4 and 5.

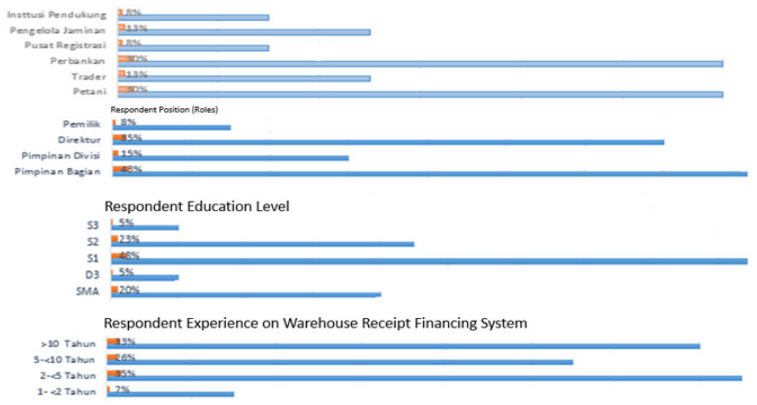

Figure 4. The respondents Qualification

The respondents of the study are mostly member of stakeholders system that have a managerial position, good education level and experience with the system. Respondents from financial institutions have a middle management position, are well-educated at bachelor level and have experience.more than 3 years using the system.

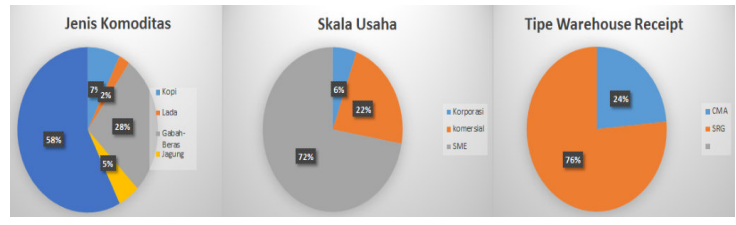

Figure 5. Commodities of Financing

Based on the data of the commodities being analyzed, coffee bean is the most suit commodity financed by warehpuse receipt system in Indonesia and SRG system is the most known by the customers.

\subsection{The Analysis}

The key characteristics of agricultural commodity financing on a warehouse receipt system, where the basic commodity producer in rural areas and the commodity trader have been studied from the financing perspective and the analysis was carried out using Structured Equation Modeling Analysis - Partial Least Squares (SEM-PLS) have produced the following results. Using 56 indicators to confirm 14 (fourteen) exogenous element of variables, the outer model is built as an exogenous variable construct model to identify the element of product acceptability for warehouse receipt systems. The exogenous variables (element variables) are grouped in 4 dimensions to construct the inner model of the endogenous variable. The inner model would show the relationship between dimensional variables in formative construct to build product acceptability. Hence, the analysis was performed in two stages of the outer model and formative indicators on the inner model.

4.2.1. Outer Model

External elements consist of 14 variables of the warehouse receipt financing system were identified. The element variables in reflective models as described in Figure 6. The validity of the indicators is determined by the value of 
validity " $r$ " that is reflected in the loading factor with a value greater than $0.5(>0.50)$ to state the validity of the indicator. Validity is the quality of measuring the external variables of the construct under the PLS model.

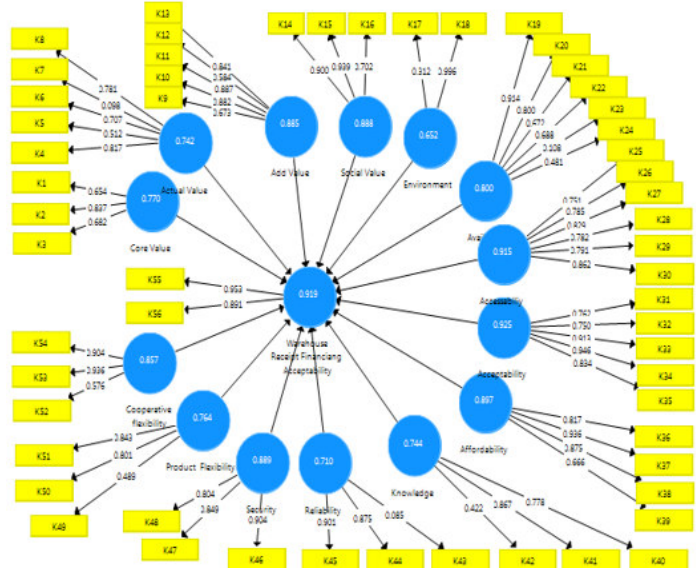

Figure 6. Construct of outer model and determinant variables of WRF system

Validity of each indicator as stated by the value of the loading factor for the outer model. It generally shows a significant validity value above 0.5 . There are indicators with a validity value of less than 0.5 . Based on Chin (1988), these indicators should be excluded from the construct model being built. Reliability of external variables should be established to prove the consistency and accuracy of the instrument when measuring the model construct. The PLS model is used to determine the construct's ability to explain variance, using a composite reliability value, a Cronbach value and an Average Variance Extracted value, their reliability is summarized in Table 1.

\begin{tabular}{lcclll}
\multicolumn{6}{l}{ Table. 1. Reliability of Outer Model variables } \\
Variables & Indicator & $\begin{array}{l}\text { Composite } \\
\text { Reliability }\end{array}$ & $\begin{array}{l}\text { Cronbach's } \\
\text { Alpha }\end{array}$ & $\begin{array}{l}\text { Average } \\
\text { Variance } \\
\text { Extracted }\end{array}$ & Remarks \\
\hline Core Value & K01-K03 & 0.770 & 0.547 & 0.531 & \\
Actual Value & K04-K08 & 0.742 & 0.621 & 0.509 & Reliable \\
Add Value & K09-K13 & 0.885 & 0.834 & 0.613 & Reliable \\
Social Value & K14-K16 & 0.889 & 0.807 & 0.728 & Reliable \\
Environment & K17-K18 & 0.652 & 0.572 & 0.544 & Unreliable \\
Availability & K19-K24 & 0.800 & 0.729 & 0.540 & Reliable \\
Accessibility & K25-K29 & 0.915 & 0.888 & 0.641 & Reliable \\
Acceptability & K31-K35 & 0.925 & 0.899 & 0.714 & Reliable \\
Affordability & K36-K39 & 0.897 & 0.846 & 0.688 & Reliable \\
Information & K40-K41 & 0.744 & 0.681 & 0.511 & Reliable \\
Knowledge & K43-K46 & 0.737 & 0.645 & 0.528 & Reliable \\
Comfortability & K47-K49 & 0.889 & 0.812 & 0.729 & Reliable \\
Flexibility value & K50-K52 & 0.764 & 0.635 & 0.631 & Reliable \\
Flexibility attribute & K53-K54 & 0.857 & 0.775 & 0.657 & Reliable \\
Acceptability. & K55-K56 & 0.919 & 0.831 & 0.851 & Reliable \\
\hline
\end{tabular}

The external variables reflect the acceptability of commodity financing in the warehouse receipt system. Multi-factor variables (external variables), as key determinants for the acceptability of warehouse receipt financing, are characterized by core value, real value, added value and social value and supported by product attributes of availability, acceptability, accessibility and affordability. Other variables, such as information for awareness and knowledge, are also a significant factor in ensuring that the customer is willing to use the products. It is known that the economic value and social value are the expected values that will be present in the product based on PLS model. However, product attributes such as availability, acceptability, accessibility and affordability should also become considerable elements to improve the system. In addition, the information provision and knowledge and reliability of the system are still essential factors for the customer to have confidence and trust in the use of the warehouse receipt financing system.

\subsubsection{Inner Model - Without Adaptability}

The inner model examines the relationship between latent variables in a formative model to construct the acceptability of the warehouse receipt financing system. The manifest variables based on PLS model in the outer model above consists of 10 variables whose measures become indicators of dimensional variables (latent variables) and dimensional variables in a formative model for latent endogenous variables as in figure 7 . The construction is as follows: First, the product value dimension $\left(\mathrm{Y}_{1}\right)$ is indicated by real value $\left(\mathrm{X}_{2}\right)$, added value $\left(\mathrm{X}_{3}\right)$ and social value $\left(\mathrm{X}_{4}\right)$. Second, the dimensions of the product attributes $\left(\mathrm{Y}_{2}\right)$ are indicated by the variables availability $\left(\mathrm{X}_{6}\right)$, accessibility $\left(\mathrm{X}_{7}\right)$, acceptability $(\mathrm{X} 8)$ and affordability of the product that is accessible to the customers $\left(\mathrm{X}_{9}\right)$. Third, the dimensions of awareness and trust to use the product $\left(\mathrm{Y}_{3}\right)$ are indicated by variables of information provision $\left(\mathrm{X}_{10}\right)$, product knowledge $\left(\mathrm{X}_{11}\right)$ and product reliability $\left(\mathrm{X}_{12}\right)$, while product acceptability $\left(\mathrm{Y}_{5}\right)$ determines $\mathrm{Y}_{1}, \mathrm{Y}_{2}$ and $\mathrm{Y}_{3}$. The performance of acceptability of the warehouse receipt financing system $\left(\mathrm{Y}_{5}\right)$ is indicated by the 
transaction volume $\left(\mathrm{K}_{55}\right)$ and product distribution $\left(\mathrm{K}_{56}\right)$. The relationship between the above variables and the formative construct for acceptability of commodity financing is indicated by the inner construct shown in Figure 7 and the validity of the measured variables as in Table 2.

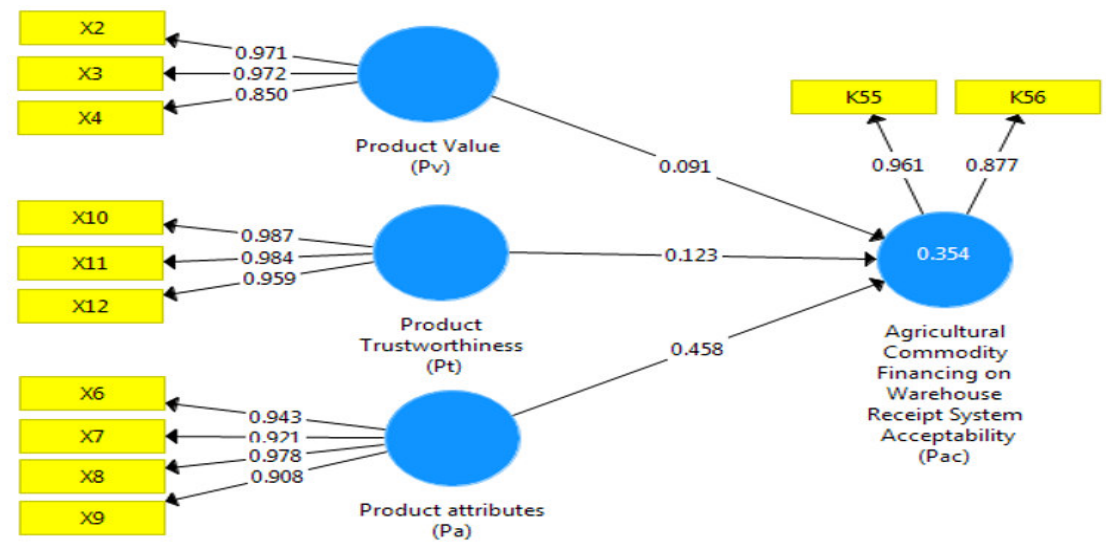

Picture 7. Acceptability Variables to WRF (Without adaptability)

Table 2.Validity of variable inner model

\begin{tabular}{llll}
\hline Code & Variables & $\begin{array}{l}\text { Outer } \\
\text { Loading }\end{array}$ & Validity \\
\hline X2 & Real Value & 0.971 & Valid \\
X3 & Add Value & 0.972 & Valid \\
X4 & Social Value & 0.850 & Valid \\
X6 & Availability & 0.943 & Valid \\
X7 & Accessibility & 0.921 & Valid \\
X8 & Acceptability & 0.978 & Valid \\
X9 & Affordability & 0.908 & Valid \\
X10 & Information & 0.987 & Valid \\
X11 & Knowledge & 0.984 & Valid \\
H12 & Comfortability & 0.959 & Valid \\
K55 & Transaction Volume & 0.961 & Valid \\
K56 & Product distribution & 0.877 & Valid \\
\hline
\end{tabular}

Based on Figure 7 and Table 2, the given variables are valid to reflect the latent variables of the inner model of PLS above. Reflective indicators of dimensional variables with a loading factor greater than $>0.5$ (Chin at al., 2003) are accepted as valid indicators of inner models to construct the construction of product benefit values (Y1), product attributes (Y2), and trust in the product (Y3). The assessment of the reliability of the construct of the inner model is determined by the composite reliability value, Cronbach's value and Extracted as are summarized in Table 3.

Table 3. Reliability of construct variables inner model - without adaptation

\begin{tabular}{|l|l|l|l|l|l|}
\hline $\begin{array}{l}\text { Product } \\
\text { Variable }\end{array}$ & Indicator & $\begin{array}{l}\text { Composite } \\
\text { Reliability }\end{array}$ & $\begin{array}{l}\text { Cronbach's } \\
\text { Alpha }\end{array}$ & $\begin{array}{l}\text { Average } \\
\text { Variance } \\
\text { Extracted }\end{array}$ & Remarks \\
\hline Value & X2-X4 & 0.952 & 0.923 & 0.870 & Reliable \\
\hline Attribute & X6-X9 & 0.967 & 0.954 & 0.880 & Reliable \\
\hline Trust & X10-X12 & 0.984 & 0.976 & 0.954 & Reliable \\
\hline Acceptability & K55-K56 & 0.917 & 0.831 & 0.847 & Reliable \\
\hline
\end{tabular}

To determine the relationship between variables as a confirmatory factor in a formative model to develop system acceptability, data iterations were carried out up to 5000 times of iteration using PLS and bootstrapping. The iteration or bootstrapping process for the statistical significance testing process generated path coefficients, Cronbach's alpha, and $\mathrm{R}^{2}$ values to obtain information about the relationship between variables. Based on the results of PLS analysis, the relationship between the dimensions value, attributes and trust in acceptability is positive, as shown by the values of the path coefficient, each of which is positive $(0.091,0.458,0.123)$ and the R2-Square construct model is $0.354(35 \%)$. 


\subsubsection{Inner Model - With Adaptability}

In order to develop the continuity of acceptability, this paper uses conceptual adaptability with flexibility as an intervention model to respond to the environment. Product value, product attributes and trust as measured in the first stage make it possible to adapt flexibly to the environment. Hence, the construct of the product acceptability variable (Y5) will consequently be formatted by product value (Y1), product attribute (Y2), product trustworthiness (Y3) and product adaptability (Y4). The adaptability of the product is indicated by the flexibility to optimize the value of the product and its system (X13) and the flexibility to optimize the coordination of the system with the exterior of the system (X14). The relationship of the variables is illustrated by the inner model construct of (formative) variables in Figure 8 and the validity of each variable in Table 4.

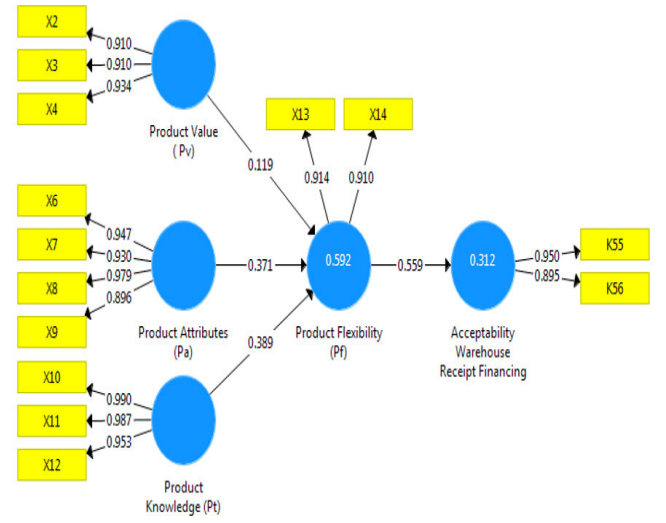

Figure 8. Acceptability to WRF supported by flexibility to adapt.

Table 4 .Validity of variables inner model

\begin{tabular}{llll}
\hline Code & Variables & $\begin{array}{l}\text { Outer } \\
\text { Loading }\end{array}$ & Validity \\
\hline X2 & Actual/real Value & 0.910 & Valid \\
X3 & Add Value & 0.910 & Valid \\
X4 & Social Value & 0.934 & Valid \\
X6 & Availability & 0.947 & Valid \\
X7 & Accessibility & 0.950 & Valid \\
X8 & Acceptability & 0.978 & Valid \\
X9 & Affordability & 0.896 & Valid \\
X10 & Information & 0.990 & Valid \\
X11 & Knowledge & 0.987 & Valid \\
X12 & Comfortability & 0.953 & Valid \\
X13 & Flexibility (Value) & 0.914 & Valid \\
X14 & Flexibility (Attributes) & 0.910 & Valid \\
K55 & Transaction Volume & 0.950 & Valid \\
K56 & Product distribution & 0.895 & Valid \\
\hline
\end{tabular}

Based on Figure 8, the inner model of PLS above is reflected by indicators of dimensional variables with a loading factor greater than $>0.5$ (Chin at al., 2003) and are therefore accepted as valid indicators of inner models of product benefit values (Y1), product attributes (Y2), trust in the product (Y3) and product adaptability (Y4) as detailed in Table 4. The assessment of the reliability of the construct of the inner model is determined by the composite reliability value, Cronbach's value and Extracted as are summarized in Table 5.

Table 5. Reliability of construct variables inner model - with adaptation

\begin{tabular}{|l|l|l|l|l|l|}
\hline $\begin{array}{l}\text { Product } \\
\text { Variable }\end{array}$ & Indicator & $\begin{array}{l}\text { Composite } \\
\text { Reliability }\end{array}$ & $\begin{array}{l}\text { Cronbach's } \\
\text { Alpha }\end{array}$ & $\begin{array}{l}\text { Average Variance } \\
\text { Extracted }\end{array}$ & Remarks \\
\hline Value & X2-X4 & 0.942 & 0.923 & 0.843 & Reliable \\
\hline Attribute & X6-X9 & 0.967 & 0.954 & 0.880 & Reliable \\
\hline Trust & X10-X12 & 0.984 & 0.976 & 0.954 & Reliable \\
\hline Flexibility & X13-X14 & 0.908 & 0.798 & 0.832 & Reliable \\
\hline Acceptability & K55-K56 & 0.920 & 0.831 & 0.852 & Reliable \\
\hline
\end{tabular}

4.3. The relationship between product adaptation and acceptability

The relationship between variables in the formative construct of construct acceptability is developed by iterating data samples up to 5000 times. The iteration or bootstrapping process produces path coefficients, Cronbach's alpha, 
$\mathrm{R}^{2}$ values and Q2, as illustrated by the PLS data resulting in Table 5. The relationship the dimensional variables and additional adaptation variables to respond to changes in the environment, is described as follows. First, product value, product attributes and trust in the product have a positive relationship to product flexibility, as indicated by the positive value of the path coefficient of each dimension variable $(0.119,0.371$, and 0.389$)$. Second, the $\mathrm{R}_{1}$-Square of the construct model between dimensional variables with flexibility is $0.592(59 \%)$ and the $\mathrm{R}_{2}$ square of construct flexibility to acceptability is $0.312(31 \%)$. R-square indicates the model's ability to explain the variation of the dependent variable; according to Chin (2003): R-square $>0.67$ (strong), R square $>0.33$ (moderate) and R square $>0.19$ (weak). Third, the decision on the relevance of the adaptation variable for flexibility and acceptability is determined by the predictive relevance value or Q-square $\left(\mathrm{Q}^{2}\right)$ of Stone-Geisser's, calculated as formula $\mathrm{Q}^{2}=1-\left(1-\mathrm{R}_{1}{ }^{2}\right)\left(1-\mathrm{R}_{2}{ }^{2}\right)$. With data of $\mathrm{R}_{1}{ }^{2}=0.592$ and $\mathrm{R}_{2}{ }^{2}=0.312$, the predictive relevance $\left(\mathrm{Q}^{2}\right)$, based on the values of $\mathrm{R}_{1}{ }^{2}$ and $\mathrm{R}_{2}{ }^{2}$, is calculated 0.586 (59\%). According to Chin, Q square 0.02 is (small), 0.15 (moderate) and $>0.35$ (large) so that the relevance of the flexibility variable relationship increases acceptability by $59 \%$ (large). Four, hypothesis test, further to the purpose of the study to test the hypothesis that product flexibility increases the acceptability of the product. The research hypothesis test was proven by the $t$-value of a statistical test: the value of $t$-test $=4.314$ at a significant level at $95 \%(\alpha=0.05$ and, $t$-table $=1.96)$. The hypothesis is rejected if $\mathrm{H}_{0}=0$ or $\mathrm{t}$-test $\leq \mathrm{t}$-table; hypothesis is accepted if $\mathrm{H}_{1} \neq 0$ or $\mathrm{t}$-test $\geq \mathrm{t}$-table. On the basis of this t-test value, it can be concluded that the flexibility variable has impact on the acceptability of the SRG system of commodity financing,

\section{5, Conclusions and Recommendation Conclusions}

This paper studies the key characteristics of warehouse receipt financing that are suitable to be developed based on the local environment. We found that warehouse receipt systems in Indonesia have the following characteristics (i) the products should be developed for economic benefit and social purpose. Economic value is financial benefits such as cost, price and return that are real and contribute to the customer from warehouse receipt financing. Furthermore, in addition to economic benefits, warehouse receipt financing should also be developed for social value, particularly for small businesses or small farmers; (ii) the product must be developed in an accessible manner, it must be supported by product attributes such as availability of the product on the market, acceptability of regulations, terms and conditions and product features, accessibility to reach product locations, including accessibility to reach information and affordability to price, costs and risk of a product; (iii) product development must be supported by information, knowledge and relationships to build trust in the product; (iv) the product adaptability can be proved increasing markets acceptability.

\section{Recommendation}

Subsequent research is expected to be able to consider other factors that can be acceptable besides the variables in this study which including local characteristics that tend to be different among commodities producers in different location in Indonesia. Further research can take other commodities, business size and financing model which suit with environment conditions.

\section{References}

Ashari (2012). Potensi dan Kendala Sistem Resi Gudang Untuk Mendukung Pembiayaan Usaha Pertanian di Indonesia. Pusat Sosial Ekonomi dan Kebijakan Pertanian, Bogor.

Becchetti, L., Conzo, P. (2009). Creditworthiness as a signal of trustworthiness: field experiment in microfinance and consequences on causality in impact studies.

Bustamin (2014). Management Strategy of Warehouse Receipt System on coconut commodities, Management Department, Faculty of Economics and Business, Universitas Brawijaya, Indonesia.

Capacio, Emmanuel, Tulder, R. (2018). Breaking barriers in agriculture financing: Enhancing the inclusiveness and sustainability of agriculture value chains, University of Philipines.

Chin, W. W., Marcolin, B. L., \& Newsted, P. R. (2003). A Partial Least Squares Latent VariableModeling Approach For Measuring Interaction Effects: Results From A Monte Carlo Simulation Study And Electronic Mail Emotion/Adoption Study, Information Systems Research, 14(2), 189-217.

Coulter and Onumah (2002). The role of warehouse receipt systems in enhanced commodity marketing and rural livelihoods in Africa, Natural Resources Institute, Central Avenue, Chatham Maritime, Kent ME4 4TB, UK

Gashayie A. and Singh M. (2015). Agricultural Finance Constraints and Innovative Models Experience for Ethiopia: Empirical Evidence from Developing Countries, Punjabi University, India.

Gunawan, E., Kuwornu, J., Nguyen, ADLT. (2019). Farmers' Perceptions of the Warehouse Receipt System in Indonesia, Department of Food, Agriculture and Bioresources, School of Environment, Klong Luang, Pathumthani 12120, Thailand

Hananu, B., Hanan, A. A., \& Zakaria, H. (2015). Factors Influencing Agricultural Credit Demand in Northen 
Ghana. African Journal of Agricultural Research, 10(7), 645-652. https://doi.org/10.5897/AJAR2014.

IFC (2015). "Warehouse Finance and Warehouse Receipt Systems: A Guide for Financial Institutions in Emerging Economies." Technical Report, The World Bank, Washington, DC.

Jovicic, D., Jeremic L., Milicevic, M., Zeremski, A. (2014). Warehouse Receipts Functioning to Reduce Market Risk, Ministry of Education, Science and Technological Development of the Republic of Serbia.

Katunze, M,, Kuteesa, A., Mijumbi, T,, Mahebe, D. (2017).Uganda Warehousing Receipt System: Improving Market Performance and Productivity, Uganda African Development Review, Vol. 29, No. S2, 2017, 135146

Listiani, N.and Haryotejo, B. (2013). Implementasi Sistim Resi Gudang (SRG) pada komoditas jagung, Pusat Penelitian Ekonomi (P2E) LIPI, 2013

MacNamara, J. (2001). Structured Trade and Commodity Finance in Emerging Market, Woodhead Publishing Limited, Cambridge, England.

Modigliani, F., and Miller, M. H. (1958). The cost of capital, corporation finance and the theory of investment. American Economic Review, 48(3), 261-295.

Miranda, M.J., Mulangu, F., Francis, H., Kemeze (2017). Warehouse Receipt Financing for Smallholders in Developing Countries: Short on Logic, Long on Imagination, the Ohio State University, Columbus.

Rutten L. (2015). The use of warehouse receipt finance in agriculture in transition countries, World Grain Forum 2009. St. Petersburg / Russian Federation 6-7 June 2009 https: //www.researchgate.net/publication/242578672

Stiglitz, J.E., and Weiss, A. (1981). Credit Rationing In Market with Imperfect Information, the American Economic Review, June 1981.

Suryani, E., Erwidodo, Setiadjie, I. (2014). Sistem Resi Gudanga di Indonesia Antara Harapan dan Kenyataan. BOGOR. Institut Pertanian Bogor.

Sutak P., (2008). Structured Commodity Finance, Agro inform Publishing House, Budapest Budapest, 2008

Teece, D.J., Pisano, G. and Shuen, A., (1997). Dynamic capabilities and strategic management. Strategic Management Journal, 18, 509-533.

Varangis, P., and Larson, D. (2002). "How Warehouse Receipts Help Commodity Trading and Financing." World Bank, Washington, DC. 2002.

Varangis, P. and Saint-Geours, J. (2013). Warehouse Finance and Warehouse Receipt Systems: A Guide for Financial Institutions in Emerging Economies. Technical Report, The World Bank, Washington, DC.

Wang, C. L. and Ahmed, P. K. (2007). Dynamic capabilities: a review and research agenda. The International Journal of Management Reviews, 9(1): 31-51.

Wang, L, Xu, T., and Zhu, S. (2018). Supply Chain Decision-Making Based on Warehouse Receipt, Pledge and Risk Consideration under Twice Ordering Mode, School of Economics and Business Administration, Xi'an University of Technology, Xi'an 710048, China.

Wold, H., (1985). Partial least squares. In S. Kotz \& N. L. Johnson (Eds.), Encyclopedia of statistical sciences, 6 (pp. 581-591). New York: Wiley. 